\title{
Cyclic Adenosine Monophosphate, Inositol 1,4,5-trisphosphate, Calcium, and Phosphorylated Myosin Light Chain Regulation Through M2 and M3 Muscarinic Receptors of Scleral Fibroblast Cells in Rat Myopia Model
}

\author{
Nanda Wahyu Anandita ${ }^{1,2 *}$, Nurdiana Nurdiana ${ }^{3}$, Endang Sri Wahyuni ${ }^{4}$, Hidayat Sujuti ${ }^{2}$ \\ ${ }^{1}$ Doctoral Program of Medical Science, Faculty of Medicine, Universitas Brawijaya, Malang, East Java, Indonesia; ${ }^{2}$ Department \\ of Ophthalmology, Faculty of Medicine, Universitas Brawijaya, Dr. Saiful Anwar Hospital, Malang, East Java, Indonesia; \\ ${ }^{3}$ Department of Pharmacology, Faculty of Medicine, Universitas Brawijaya, Malang, East Java, Indonesia; ${ }^{4}$ Department of \\ Physiology, Faculty of Medicine, Universitas Brawijaya, Malang, East Java, Indonesia
}

\section{Abstract}

Edited by: Ksenija Bogoeva-Kostovska Citation: Anandita NW, Nurdiana N, Wahyuni ES Sujuti H. Cyclic Adenosine Monophosphate, Inositol 1,4,5-trisphosphate, Calcium, and Phosphorylated Myosin Light Chain Regulation Through M2 and M3 Muscarinic Receptors of Scleral Fibroblast Cells in Rat Myopia Model. Open Access Maced J Med Sci. 2021 Aug 26; 9(B):890-899.
https://doi.org/10.3889/oamjms.2021.6752 Key words: Phosphorylated Myosin Light Chain; Myopia Sclera; Himbacine; Methoctramin Correspondence: Nanda Wahyu Anandila, Department of Ophthalmology, Faculty of Medicine, Universitas Indonesia E-mail: nan anandita East Java, Received: 30-Jun-2021 Revised: 13-Jul-2021 Accepted: 16-Aug-202

Copyright: ๑ 2021 Nanda Wahyu Anandita, Nurdian Nurdiana, Endang Sri Wahyuni, Hidayat Sujuti unding: Research and Community Service Unit, Faculty of Medicine, Universitas Brawijaya, No. 7/SK/UN10. $\mathrm{F} 08.06 / \mathrm{KS} / 2019$
$\mathrm{n}$

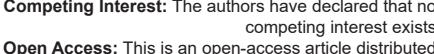
under the terms of the Creative Commons AtributionNonCommercial 4.0 International License (CC BY-NC 4.0)
AIM: This study aims to investigate the concentration of cyclic adenosine monophosphate (cAMP), inosito 1,4,5-trisphosphate (IP3), calcium $\left(\mathrm{Ca}^{2+}\right)$, and the expression phosphorylated myosin light chain (MLC) in Rattus norvegicus scleral fibroblast cells.

METHODOLOGY: This study utilized an in vitro experimental study by applying Rattus norvegicus scleral fibroblast cell culture. The cultured cells were divided into control and lens-induced myopia (LIM) groups. The control and LIM culture groups were each divided into five groups, namely, negative control, $0.1 \mu \mathrm{M}$ acetylcholine, $0.1 \mu \mathrm{M}$ himbacine $0.1 \mu \mathrm{M}$ methoctramine, and $0.1 \mu \mathrm{M} 4$-DAMP group. The CAMP, IP3, and $\mathrm{Ca}^{2+}$ concentration were analyzed in the $0^{\text {th }}$, $5^{\text {th }}, 10^{\text {th }}, 20^{\text {th }}$, and $30^{\text {th }}$. The phosphorylated MLC expression was analyzed using confocal microscope.

RESULTS: In the LIM group, the highest cAMP concentration is visible at the $10^{\text {th }}$ min on the himbacine group $(0.304 \pm 0 ; p=0.043)$ and on the 4-DAMP group $(0.346 \pm 0 ; p=0.043)$. The highest IP3 concentration is found on the LIM group at the $20^{\text {th }}$ min in comparison to the control group $(2503.6 \pm 11$ vs. $2039.2 \pm 2.1 ; p=0.046)$. The highest $\mathrm{Ca}^{2+}$ concentration belongs to the 4-DAMP treatment group from the $5^{\text {th }}$ to the $30^{\text {th }} \mathrm{min}$. The highest average phosphorylated MLC expression value in the LIM group is shown by the $0.1 \mu \mathrm{M}$ 4-DAMP treatment $(184.2 \pm 37.9 \mathrm{c}$ au)

CONCLUSION: The regulation of CAMP, IP3, $\mathrm{Ca}^{2+}$, and phosphorylated MLC on the M2 and M3 muscarinic recepto of the scleral fibroblast cells of myopia animal models differs from normal animal models which may be due to interactions of $\mathrm{M} 2$ and $\mathrm{M} 3$ muscarinic receptor as compensation reaction or crosstalk on myopia induction.

\section{Introduction}

Myopia is the most prominent cause of refractive error as a result of the elongation of the anteroposterior eyeball diameter. Especially in children, along with growth period, the anteroposterior region of the eyeball becomes longer and increases the degree of myopia. There are some complications of high myopia which lead to blindness. It is important to control the elongation of the eyeball so that the degree of myopia can be managed and blindness caused by myopia can be prevented. Sclera is the outer layer of the eyeball wall responsible for the shape and length of the eyeball. The higher the degree of myopia is, the thinner the sclera will be. There are many studies about controlling myopia with sclera targeting. The sclera consists of fibroblast cells and extracellular tissue. The scleral biomolecular pathogenesis of myopia is not yet known with certainty [1], [2], [3].
The previous study showed that cyclic adenosine monophosphate (cAMP) had a role in scleral remodeling in the development of myopia in animal myopia model [4], [5]. cAMP is an intracellular second messenger that is stimulated by adenylyl cyclase (AC) through coupled $\mathrm{G}$ protein receptor (GPCRs). The cAMP is involved in controlling cellular function and proliferation through protein kinase $C$ pathway. The cAMP can affect the inositol 1,4,5-triphosphate through protein kinase $A$ (PKA) that will phosphorylate the inositol 1,4,5-trisphosphate (IP3) receptor in the endoplasmic reticulum (ER) membrane and open the calcium $\left(\mathrm{Ca}^{2+}\right)$ gate, resulting in $\mathrm{Ca}^{2+}$ release from its storage in ER to the cytosol [6], [7], [8].

Inositol 1,4,5-triphosphate is a second messenger derived from phosphatidylinositol (PIP2) in cellular phospholipid membrane, that is hydrolyzed by phospholipase C (PLC), which was stimulated by M3 muscarinic receptor, into diacylglycerol (DAG) and IP3. The inositol 1,4,5-triphosphate will bind to the IP3 
receptor in the $\mathrm{ER}$ membrane $\mathrm{Ca}^{2+}$ gate. Therefore, the $\mathrm{Ca}^{2+}$ will open and release the $\mathrm{Ca}^{2+}$ to cytosol which stimulates many intracellular activities [7], [9], [10], [11]. Literature findings explained that during the process of myopic induction, fibroblast cells contract as a compensation to maintain eyeball length. One indicator of the fibroblast cell contraction is the phosphorylated myosin light chain (MLC), a small unit polypeptide in myosin [12], [13], [14], [15].

There is yet any certainty about the effect of a non-canonical cAMP pathway to IP3 and phosphorylated MLC in scleral fibroblast cell through a muscarinic receptor in relation to myopia pathogenesis. In this study, we investigated the role of cyclic adenosine monophosphate (cAMP), IP3 activities, phosphorylated MLC, and their connection with a muscarinic pathway in scleral fibroblast cell by giving acetylcholine as muscarinic receptor agonist, himbacine, and methoctramine as selective M2 muscarinic receptor antagonist, 4-DAMP as selective M3 muscarinic receptor antagonist.

\section{Materials and Methods}

The design of this study was an in vitro study in rat's scleral fibroblast cells culture, conducted in Biosains laboratory, Biomedical Laboratory at the Faculty of Medicine and Central Laboratory of Life Science Brawijaya University in February 2020. It has been approved by the Ethical Team of Bioscience Laboratory of Universitas Brawijaya, Indonesia. The axial length of the eyeball, fibroblast cell morphology, cAMP activity, IP3 activity, and phosphorylated MLC expression in the control group and lens-induced myopia (LIM) group were analyzed in this study. Each group was divided into a negative control group, acetylcholine group, himbacine group, methoctramine group, and 4-DAMP group. Before performing the culture, measurements of the axial length of the eyeball of the control and LIM groups were carried out and the morphology changes of the scleral fibroblast cells of the control and LIM groups were analyzed. The cAMP, IP3, and $\mathrm{Ca}^{2+}$ activities were observed at the $0^{\text {th }}, 5^{\text {th }}, 10^{\text {th }}, 20^{\text {th }}$, and $30^{\text {th }}$ min in each group. The cAMP and IP3 were analyzed using ELISA. The $\mathrm{Ca}^{2+}$ activity was analyzed using CaFluo and the phosphorylated MLC expression was analyzed using immunofluorescence staining and was observed using a confocal microscope.

\section{Animal myopia model}

The animal model testing in this study has fulfilled the ethical criteria of the Bioscience Institute of Brawijaya University and has been granted a certificate of ethical conformance from the Bioscience of Brawijaya
University, Malang, Indonesia No. 103-KEP-UB-2020. This study used the right eye of Rattus norvegicus, male, 4 weeks old, 150-200 g. They were divided into control group $(n=5)$ and treatment group $(n=5)$. The myopia was induced using the LIM method. Before installing the lens, peritoneal injection of $0.03 \mathrm{ml}$ ketamine and $0.02 \mathrm{ml}$ xylazine was performed for anesthesia during suturing the CR 39 multicoat lens with the power S-10.00 D, $10 \mathrm{~mm}$ diameter with $14 \mathrm{~mm}$ rubber frame in the rat's periorbital right eye. The LIM method was performed for 2 weeks. After 2 weeks of LIM treatment, the rat was decapitated, and the right eye was enucleated. Two observers measured the axial length using a digital caliper. The rats that experienced an infection or ocular inflammation caused by periorbital suturing during the study were excluded from the study.

\section{Cell culture of primary scleral fibroblast}

The sclera was obtained from the 4-weekold rat eyeballs that had undergone LIM treatment and had not undergone LIM treatment as the control group. The whole sclera was dissected enzymatically using $0.5 \mathrm{mg} / \mathrm{ml}$ collagenase 1 and washed with cold PBS very carefully 3 times. The sclera was placed in a $60 \mathrm{~mm}$ cultured dish with Dulbecco's modified Eagle's medium (Gibco). The medium was supplemented with penicillin, streptomycin, and amphotericin B. The 10\% fetal bovine serum (FBS; Gibco) was added. The cells cultured were incubated at $37^{\circ} \mathrm{C}, 5 \% \mathrm{CO} 2$, and allowed to reach $80 \%$ confluence. After the four were passaged, the cells were exposed to $0.25 \%$ trypsin/0.5 mM EDTA at $37^{\circ} \mathrm{C}$ for $5 \mathrm{~min}$

\section{Treatment of selective antagonist for M2 and M3 muscarinic receptor}

The cultured scleral fibroblast cells were separated into the control group, which did not experience LIM treatment, and the LIM treatment group. Each of them was divided into five groups. The negative control group did not receive drug treatment; the positive control group, or acetylcholine group, was exposed to $0.1 \mu \mathrm{M}$ acetylcholine; the himbacine group was exposed to $10 \mu \mathrm{M}$ himbacine; the methoctramine group was exposed to $10 \mu \mathrm{M}$ methoctramine; and the 4-DAMP group was exposed to $10 \mu \mathrm{M}$ 4-DAMP. We analyzed each group at the $0^{\text {th }}, 5^{\text {th }}, 10^{\text {th }}, 20^{\text {th }}$, and $30^{\text {th }} \mathrm{min}$ and repeated the analysis 3 times for each of the minute marks.

\section{Elisa for cAMP assay}

This study used an ELISA kit from Abcam. After preparing the samples, thaw CAMP standard, rabbit anti-cAMP pAb, and cAMP-HRP were assembled. The sample was diluted and $100 \mu \mathrm{L}$ in was added to each microcentrifuge tube. The $50 \mu \mathrm{L}$ neutralizing buffer and 
$50 \mu \mathrm{L}$ acylating reagent were added in each standard and test sample tube. Then, each of the tubes was mixed well with $845 \mu \mathrm{L}$ of assay buffer. Afterward, $50 \mathrm{~mL}$ acetylated standard cAMP and protein G-coated 96-well plates were prepped. The next step was to add $10 \mathrm{~mL}$ rabbit anti-cAMP $\mathrm{pAB}$ in each standard and test sample, add $10 \mu \mathrm{L} 1 \times$ assay buffer for background reading, then it was incubated for $1 \mathrm{~h}$. The $10 \mu \mathrm{L}$ cAMPHRP was added to each tube and was then incubated for $1 \mathrm{~h}$. Then, an addition of $100 \mu \mathrm{L}$ HRP developer, and incubation for $1 \mathrm{~h}$ at room temperature was carried out. The $100 \mu \mathrm{L}$ stop solution was added and read the plate at OD450 $\mathrm{nm}$.

\section{Elisa for IP3 assay}

This study used the Elisa Kit assay from MyBioSource. After preparing the sample by centrifuging the sample for $20 \mathrm{~min}$ at $1000 \times \mathrm{g}$ at $28^{\circ} \mathrm{C}$ and collecting the supernatant, the next step was to add the standard working solution to the first two columns and duplicate to one sell each at $50 \mu \mathrm{L}$ each well. The sample was added to the other well and $50 \mu \mathrm{L}$ biotinylated detection $\mathrm{Ab}$ working solution in the bottom of the microplate. Using the sealer, the plate was covered and incubated for $45 \mathrm{~min}$ at $37^{\circ} \mathrm{C}$. The solution was aspirated and added $350 \mu \mathrm{L}$ of wash buffer. Then, it was soaked for $2 \mathrm{~min}$ and the solution was aspirated from each well and was let dry in absorbent paper. This procedure was repeated for 3 times. The $100 \mu \mathrm{L}$ HRP conjugate working solution was given, then covered with plate sealer, and incubated for $30 \mathrm{~min}$ at $37^{\circ} \mathrm{C}$. The next step was to aspirate the solution and to repeat the wash process for 5 times. Then, a $90 \mu \mathrm{L}$ substrate reagent was added, covered with plate sealer, and incubated for $15 \mathrm{~min}$ at $37^{\circ} \mathrm{C}$ and protected from light. The $50 \mu \mathrm{L}$ stop solution was added and the optical density value was determined for each well with microplate reader set to $450 \mathrm{~nm}$.

\section{CaFluo for intracellular $\mathrm{Ca}^{2+}$ activity}

We used fluo-3 (sigma-aldrich 46393-1MG-F) to analyse the scleral fibroblast cell $\mathrm{Ca} 2+$ activities. Aspirate the culture media and rinse with PBS twice. Cells were given Fluo-3 treatment and incubated for 30-60 min at room temperature, carried out in dark conditions. The recovery process was carried out by adding EBSS and incubated at $37^{\circ} \mathrm{C}$ for $30 \mathrm{~min}$. Incubate for $2 \mathrm{~min}$ before observation. Cover with a glass cover and avoid exposure to light. Confocal laser scanning microscopy observation using $364 \mathrm{~nm}$ excitation with 515-560 nm emission using a confocal microscope.

\section{Immunofluorescence staining for phosphorylated MLC assay}

We used phosphor-MLC 2 (Thr 18. Ser 19) antibody (Cell signal \#3674). The specimen was blocked in a blocking buffer using bovine serum albumin for $30 \mathrm{~min}$. The preparation of primary antibody was by diluting as indicated on the datasheet in antibody dilution buffer. Then, we aspirated the blocking solution, applied diluted primary phosphorylated MLC antibody, and incubated it overnight at $4^{\circ} \mathrm{C}$. We then rinsed it for 3 times in $1 \times$ PBS for 5 min each. Then, we incubated the specimen in a fluorochrome conjugated secondary antibody diluted in antibody dilution buffer for 1-2 $\mathrm{h}$ at room temperature in the dark. Next, we rinsed for 3 times in $1 \times$ PBS for 5 min each. Finally, we added coverslip slides with Prolong® Gold Antifade Reagent (\#9071).

\section{Data analysis}

Data analysis functions as a means to compare the concentration of cAMP, IP3, $\mathrm{Ca}^{2+}$, and phosphorylated MLC expression between the control and LIM groups using Mann-Whitney U-test where significant difference means that $p<0.05$ was considered.

\section{Results}

\section{Axial length changes of the eyeball and scleral fibroblast cell morphology}

After performing myopia induction using LIM method for 2 weeks, measurements of the axial length of the eyeball were performed and comparisons were made with axial lengths of the control group. Figure 1 describes the axial length of both groups $(n=5)$. The control group in which the animals did not perform shows less axial length than that of the LIM group. There was also a change in scleral fibroblast cells morphology of Rattus norvegicus in the control and LIM groups that were analyzed using a confocal microscope.

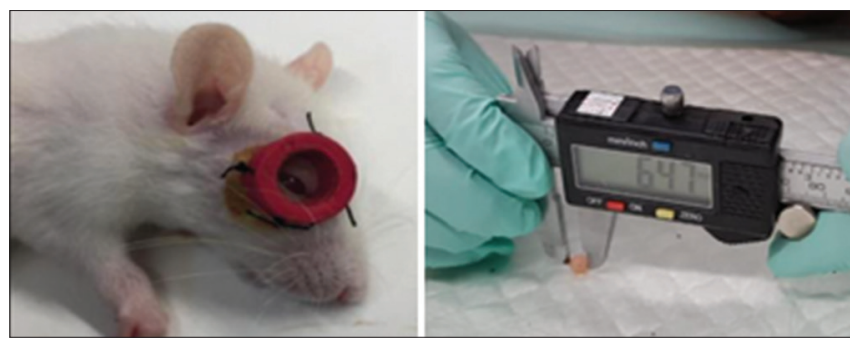

Figure 1: Lens induced myopia method and axial length measurement a) Lens-induced myopia (LIM) treatment in animal models. S-10.00 D lens with a diameter of $10 \mathrm{~mm}$ was given with a $14 \mathrm{~mm}$ rubber frame for 14 days. b) measurement of eyeball antero-posterior diameter uses digital caliper

\section{cAMP concentration}

Figure 1 presents the cAMP concentration for both the control and LIM groups of animal model. In the 
negative control group, the cAMP concentration of the LIM group is lower at the $0^{\text {th }}$ and $5^{\text {th }} \min (0.011+0 ; 0.043$ $+0 ; p<0.05)$ than the control group $(0.0233+0 ; 0.0373$ $+0 ; p<0.05)$. At the $10^{\text {th }} \mathrm{min}$, there is no significant difference between the control and the LIM groups $(0.004$ $+0 ; 0.0037+0 ; p<0.05)$. The cAMP concentration of the LIM group increased significantly compared to the control group during the $20^{\text {th }}$ min $(0.0043+0$ vs. $0.001+$ $0)$ and the $30^{\text {th }} \min (0.014+0$ vs. $0.003+0)$.

In the acetylcholine group, the cAMP concentration of the LIM group is lower than the control group at the $0^{\text {th }}$ and $5^{\text {th }} \min (0.011+0$ vs. $0.0233+$ $0, p=0.034 ;$ and $0.003+0$ vs. $0.004+0, p=0.025)$. At the $10^{\text {th }}, 20^{\text {th }}$, and $30^{\text {th }} \mathrm{min}$, the cAMP concentration of LIM group is higher than the control group $(0.0197+0$ vs . $0.009+0 ; 0.025+0$ vs. $0.002+0 ; 0.017+0$ vs. 0.002 $+0 ; p<0.05)$. The methoctramine group shows that at the $0^{\text {th }}, 5^{\text {th }}, 10^{\text {th }}$, and $20^{\text {th }} \mathrm{min}$, the cAMP concentration of LIM group is lower than the control group and at the $30^{\text {th }} \mathrm{min}$, it became higher than the control group $(0.029$ +0 vs. $0.04+0, p<0.05)$. In the himbacine treatment, the control group shows higher cAMP concentration at the $5^{\text {th }}$ min than the LIM group $(0.203+0$ vs. $0.0953+0$; $\mathrm{p}<0.05)$. Meanwhile, the LIM group shows higher cAMP concentration for the himbacine treatment at the $10^{\text {th }} \mathrm{min}$ $(0.304+0 ; p=0.043)$. For the 4-DAMP treatment, the highest CAMP concentration was identified at the $10^{\text {th }} \mathrm{min}$ of the LIM group $(0.346+0 ; p=0.043)$, while there is no significant difference between the concentrations of CAMP of both the control and LIM groups at the $30^{\text {th }} \mathrm{min}$ $(0.051+0$ vs. $0.0507+0 ; p=0.317)$.

Figure 2 shows the comparison of scleral fibroblast cell cAMP concentration while giving the antagonist M2 receptors and antagonist M3 muscarinic receptor in control and LIM group. The cAMP concentration was observed using ELISA and analyzed using Mann-Whitney U-test. The observation of cAMP level was made at the $0^{\text {th }}, 5^{\text {th }}, 10^{\text {th }}, 20^{\text {th }}$, and $30^{\text {th }}$ min where each of the control and LIM groups consists of negative control group, positive control group, or 0.1 $\mu \mathrm{M}$ acetylcholine (a non-selective muscarinic agonist), methoctramine (M2 muscarinic receptor antagonist), 0.1 $\mu \mathrm{M}$ himbacine (M2 muscarinic receptor antagonist), and $0.1 \mu \mathrm{M}$ 4-DAMP (M3 muscarinic receptor antagonist). In the control group, the highest concentration is found on the $0.1 \mu \mathrm{M}$ himbacine treatment group at the $5^{\text {th }}$ min. Meanwhile, in the LIM group, the highest cAMP concentration is found on the $0.1 \mu \mathrm{M} 4$-DAMP treatment group at the $10^{\text {th }} \mathrm{min}$ and $0.1 \mu \mathrm{M}$ himbacine treatment group at the $10^{\text {th }} \mathrm{min}$.

\section{IP3 concentration in the control and LIM groups}

The IP3 concentration of the negative control group at the $5^{\text {th }}$ min starts to show a significant difference between the control and LIM groups and is the highest IP3 concentration of the LIM group (1707.8
+1.9 vs. $2017.8+4.1 ; p=0.043)$. In the acetylcholine treatment groups, similar to the negative control group, a significant difference in terms of IP3 concentration for the control and LIM groups and the highest IP3 concentration of the LIM group appear during the $5^{\text {th }} \min (1521.8+1.7$ vs. $2219.3+5.8 ; p=0.046)$. At the $20^{\text {th }} \mathrm{min}$, the IP3 concentration of the acetylcholine treatment is highest in the control group compared to the LIM group $(2010.7+7.4$ vs. $1538.8+4.6 ; p=$ $0.000)$. In the methoctramine treatment group, the highest IP3 concentration is found on the LIM group at the $20^{\text {th }}$ min compared to the control group $(2503.6+$ 11 vs. $2039.2+2.1 ; p=0.046)$. The IP3 concentration of the himbacine treatment group during the $0^{\text {th }}, 5^{\text {th }}, 10^{\text {th }}$, and $20^{\text {th }} \mathrm{min}$, in the LIM group shows lower value in comparison to the control group, while on the $30^{\text {th }} \mathrm{min}$, the IP3 concentration of LIM group is higher than the control group $(1650.6+7.3$ vs. $1459.8+3.4 ; p=0.043)$.

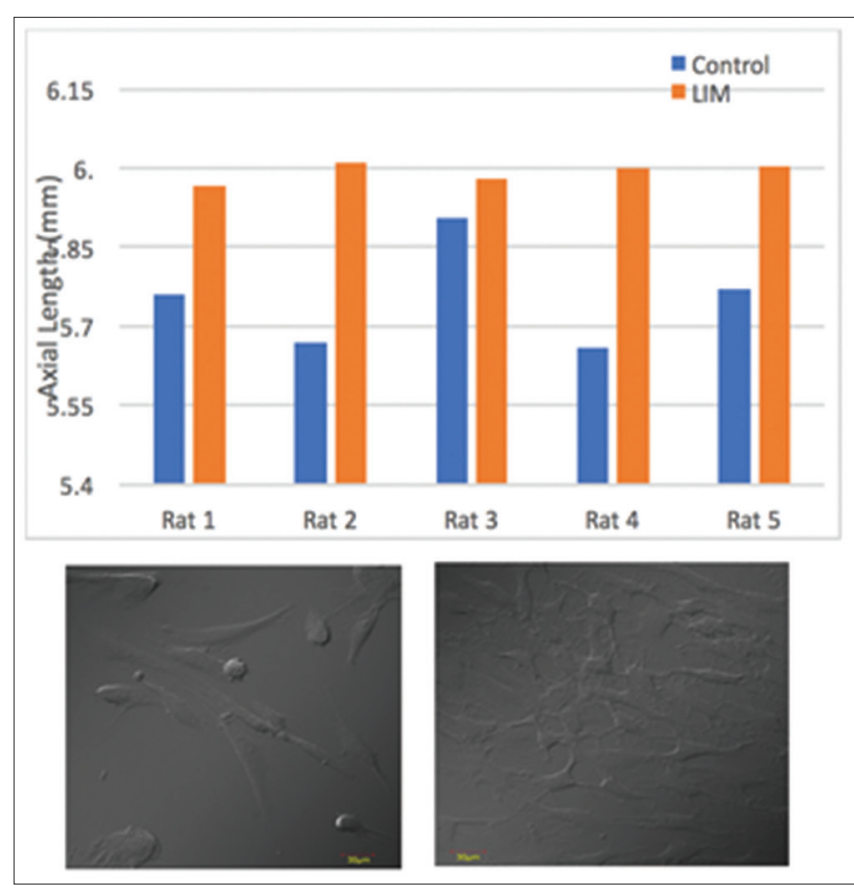

Figure 2: Axial length and scleral fibroblast cell changes. (a) Comparison between the eyeball's axial lengths of control and lensinduced myopia (LIM) treatment rat group was measured after 2 weeks of being induced with myopia. It can be concluded that the eyeball's axial lengths of the LIM group are greater than those of the control rat group. (b) Scleral fibroblast cell in Rattus norvegicus in the control group (left), scleral fibroblast cells in Rattus norvegicus in the LIM group (right); the shape of scleral fibroblast cells changes in myopia-induced rats using the LIM method for 2 weeks

Figure 3 shows the IP3 concentration of control and LIM R. norvegicus. Comparison of IP3 concentration through the M2 and M3 muscarinic receptors, throughout the observed time for the control and LIM groups using ELISA, whereas the data were analyzed using Mann-Whitney U-test. The IP3 concentration was observed at the $0^{\text {th }}, 5^{\text {th }}, 10^{\text {th }}, 20^{\text {th }}$, and $30^{\text {th }} \mathrm{min}$ where each of the control and LIM groups consists of the negative control group, positive control group. or $0.1 \mu \mathrm{M}$ acetylcholine as non-selective muscarinic agonist, $0.1 \mu \mathrm{M}$ methoctramine (M2 muscarinic receptor 
antagonist), $0.1 \mu \mathrm{M}$ himbacine (M2 muscarinic receptor antagonist), and $0.1 \mu \mathrm{M}$ 4-DAMP (M3 muscarinic receptor antagonist). In the control group, the highest concentration is found on the $0.1 \mu \mathrm{M}$ methoctramine treatment group at the $10^{\text {th }} \mathrm{min}$. Meanwhile, in the LIM group, the highest IP3 concentration is found on the 0.1 $\mu \mathrm{M}$ methoctramine treatment group at the $20^{\text {th }} \mathrm{min}$.

\section{$\mathrm{Ca}^{2+}$ activity in the control and LIM groups}

Figure 4 shows that the control group displaying the highest activity belongs to the negative control group. At the $5^{\text {th }} \mathrm{min}$, the average concentration of $\mathrm{Ca}^{2+}$ decreases in all treatment groups, which are the $0.1 \mu \mathrm{M}$ himbacine, $0.1 \mu \mathrm{M}$ methoctramine, negative control group, $0.1 \mu \mathrm{M}$ 4-DAMP treatment, and $0.1 \mu \mathrm{M}$ acetylcholine treatment. Next, there is a decrease at the $10^{\text {th }} \mathrm{min}$ on the negative control and the 4-DAMP treatment; on the $0.1 \mu \mathrm{M}$ acetylcholine, $0.1 \mu \mathrm{M}$ methoctramine, and $0.1 \mu \mathrm{M}$ himbacine, there is a little increase.

However, at the $20^{\text {th }} \mathrm{min}$, the average $\mathrm{Ca}^{2+}$ on the $0.1 \mu \mathrm{M}$ methoctramine and $0.1 \mu \mathrm{M}$ himbacine decreased again, while the $0.1 \mu \mathrm{M}$ acetylcholine remained increased. Similarly, the negative control and the $0.1 \mu \mathrm{M} 4$-DAMP treatment also experience a slight increase. At the $30^{\text {th }} \mathrm{min}$, all treatments show slight increase except for the negative control, which shows a slight decrease.

In the LIM group, the highest activity was observed on the 4-DAMP treatment group, which started from the $5^{\text {th }}$ min to the $30^{\text {th }} \mathrm{min}$. Whereas, the second highest activity is identified at the $5^{\text {th }} \mathrm{min}$ of himbacine treatment group.

Figure 4 shows the $\mathrm{Ca}^{2+}$ concentration of scleral fibroblast cells of control and LIM $R$. norvegicus. Comparison between $\mathrm{Ca}^{2+}$ concentration throughout the observed time for the control and LIM groups observed using CaFluo and examined using confocal microscope, while the data were analyzed using MannWhitney U-test. $\mathrm{Ca}^{2+}$ concentration was observed at the $0^{\text {th }}, 5^{\text {th }}, 10^{\text {th }}, 20^{\text {th }}$, and $30^{\text {th }}$ min for the control and LIM groups. In the control group, the highest concentration is found on the negative control group at the $0^{\text {th }}, 5^{\text {th }}$, $10^{\text {th }}, 20^{\text {th }}$, and $30^{\text {th }}$ min. Meanwhile, in the LIM group, the highest $\mathrm{Ca}^{2+}$ concentration is found on the $0.1 \mu \mathrm{M}$ 4-DAMP treatment group starting from the $5^{\text {th }} \mathrm{min}$.

\section{Phosphorylated MLC expression in the control and LIM groups}

Figure 5 describes the expression of phosphorylated MLC in the control and LIM groups
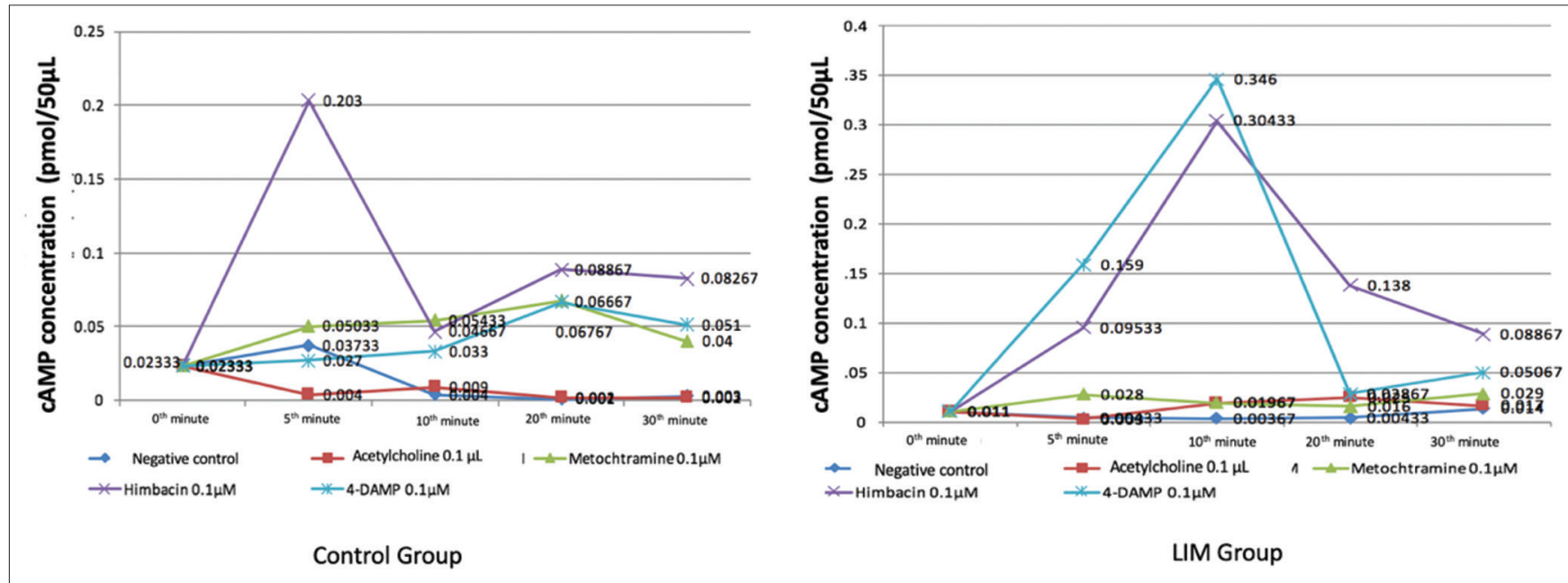

Figure 3: The cyclic adenosine monophosphate concentrations in control and lens-induced myopia Rattus norvegicus
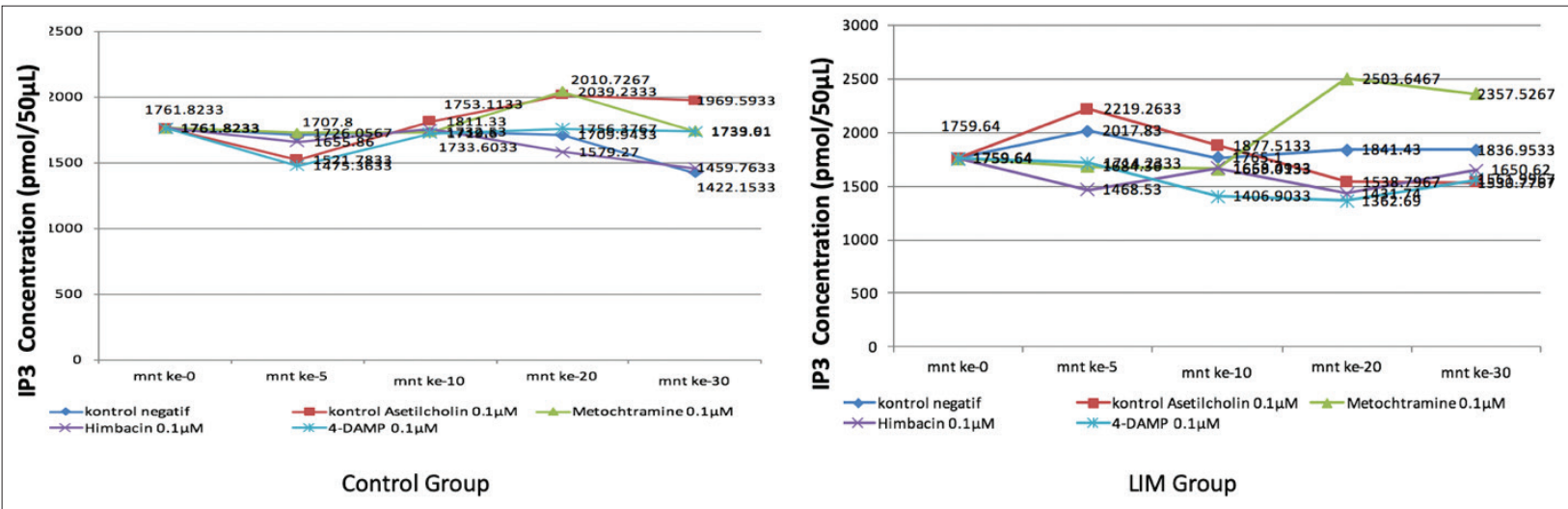

Figure 4: The inositol 1,4,5-trisphosphate concentration of control and lens-induced myopia Rattus norvegicus 


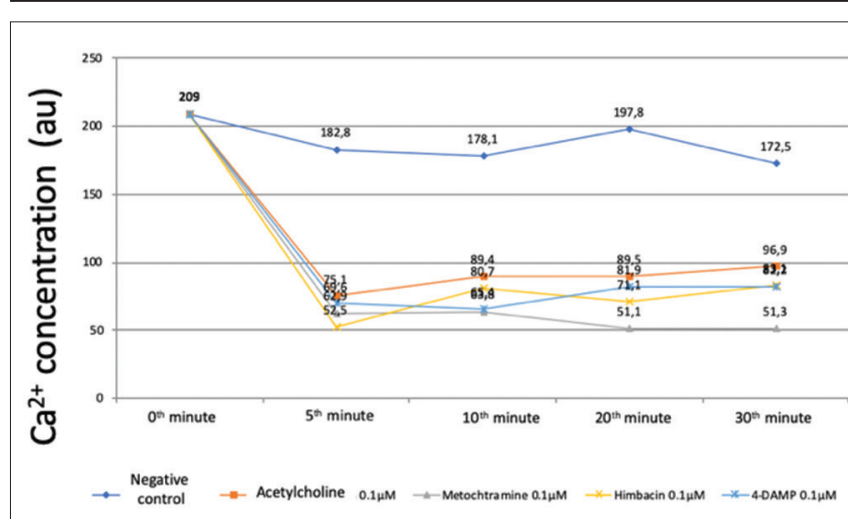

Control group

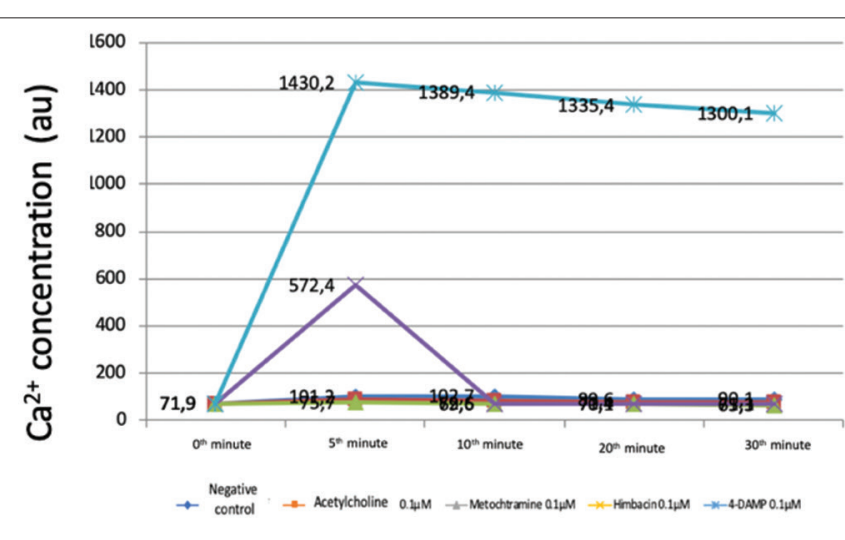

LIM group

Figure 5: The calcium concentration of scleral fibroblast cells of control and lens-induced myopia Rattus norvegicus

using an immunofluorescent assay that was analyzed using a confocal microscope. Based on the observation with confocal microscope, there is a difference in phosphorylated MLC expression between the control and the LIM groups. In the control group, no difference was found between the negative control, positive control, methoctramine, himbacine, and 4-DAMP group. Meanwhile, in the LIM group, the negative control group was the dimmer compared to the positive control group. The methoctramine, himbacine, and 4-DAMP groups are almost the same.

Based the one-way ANOVA test, the phosphorylated MLC expression on the control cells shows no significant difference in the average of the five observed sample groups, shown by $p=0.425$ which is higher than 0.05 . Figure 4 displays the histogram of the average \pm standard deviation of the phosphorylated MLC expression of the five sample groups' control cells. The highest average phosphorylated MLC expression is on the negative control group ( $333 \pm 57 \mathrm{au}$ ) and there is a decrease in the average phosphorylated MLC expression on the $0.1 \mu \mathrm{M}$ acetylcholine group (198 $\pm 81 \mathrm{au})$, and on the other treatment groups, $0.1 \mu \mathrm{M}$ himbacine ( $237 \pm 191 \mathrm{au}), 0.1 \mu \mathrm{M}$ methoctramine (243 $\pm 177 \mathrm{au})$, and $0.1 \mu \mathrm{M} 4$-DAMP $(258 \pm 146 \mathrm{au})$, though these decrease in average phosphorylated MLC expression, are not statistically significant.

Based on the one-way ANOVA test, the phosphorylated MLC expression on the LIM cells shows the significant difference in the average phosphorylated MLC expression in the five observed sample groups, indicated by $p=0.000<\propto$ Figure 5 displays the histogram of the average phosphorylated MLC expression of the negative control group, the $0.1 \mu \mathrm{M}$ acetylcholine control group, $0.1 \mu \mathrm{M}$ methoctramine group, $0.1 \mu \mathrm{M}$ himbacine group, and $0.1 \mu \mathrm{M}$ 4-DAMP group. There is an increase in the average phosphorylated MLC expression on the treatment of $0.1 \mu \mathrm{M}$ acetylcholine, $0.1 \mu \mathrm{M}$ methoctramine, $0.1 \mu \mathrm{M}$ himbacine, and $0.1 \mu \mathrm{M}$ 4-DAMP compared to the negative control. The highest value of average phosphorylated MLC expression belongs to the $0.1 \mu \mathrm{M}$ 4-DAMP group (184.2 $\pm 37.9^{\circ}$ $\mathrm{au}$ ) as well as also being the farthest from the average phosphorylated MLC expression of the negative control group $\left(50.4 \pm 9.3^{\mathrm{a}} \mathrm{au}\right)$. This means that the administering of $0.1 \mu \mathrm{M}$ acetylcholine, $0.1 \mu \mathrm{M}$ methoctramine, $0.1 \mu \mathrm{M}$ himbacine, and $0.1 \mu \mathrm{M} 4$-DAMP to the LIM cells of $R$. norvegicus rat will.

Figure 5 shows the phosphorylated MLC expression in control and LIM of scleral fibroblast cells $R$. norvegicus. Expression of phosphorylated MLC in the control and LIM groups was observed using immunofluorescence and confocal microscope at the $20^{\text {th }}$ min and analyzed using one-way ANOVA. It can be seen that across the control animal group, all of the groups are almost the same. On the other side, the negative control group shows a dimmer result compared to the acetylcholine, himbacine, methoctramine, and 4-DAMP treatment group. The histogram of phosphorylated MLC expression observed using phosphor-MLC 2 (Thr 18. Ser 19) antibody, examined using immunofluorescence with confocal microscope during the $20^{\text {th }}$ min in the control and LIM groups and the data were analyzed with one-way ANOVA. In the control group, no significant differences were found in terms of the phosphorylated MLC expression. However, the highest phosphorylated MLC expression in the LIM group was achieved by the 4-DAMP treatment group.

\section{Discussion}

The samples of our study used $R$. norvegicus rats, aged 4 weeks because of its equivalence to a human's age of 10 years in which growth and development phase take place [16]. As already stated in several theories, the progression of myopia occurs during the growth and development phase. Zhou et al. (2014) mentioned that the visual effect of age before 6 weeks is greatly influenced the refractive statistic and there were comparisons of the results of LIM and FDM induction in various studies. We treated the samples to 
stimulate myopia through the LIM method for 2 weeks. Mao et al. (2013) mentioned that they made myopia model in $R$. norvegicus with form-deprivation myopia (FDM) in guinea pig for 10 days. Wang et al. (2014) mentioned the induction of LIM in guinea pigs with an S-6.00 D lens for 14 days. This is closely similar to research by Xiao et al. (2014) which used a pig model given with S-7.00 D lens for 14 days, which induced myopia model [17], [18], [19], [20]. In our preliminary study (Figure 6a), we found that there was a change in the eyeball's axial length in our samples that received the LIM treatment compared to the control samples. This shows that the LIM treatment we did was able to make the axial length of the eyeball longer.

Figure $6 \mathrm{~b}$ shows that there is a change in sclera fibroblast cells morphology between normal and myopia-induced samples groups. It is likely that the differentiation of fibroblasts into myofibroblasts in the LIM process occurred. The path of fibroblasts differentiation into myofibroblasts in the sclera is still not known for certain. In vitro study of animal myopia model showed that in myopia development, there is tissue stress in sclera that alters the cellular mechanic. It seems that the LIM method stimulates tissue stress, prompting myofibroblast differentiation [14], [15].

We observed the changes in the nature of the sclera in the M2 muscarinic receptor pathway with the cAMP parameter and the M3 muscarinic receptor pathway with the IP3 parameter. Observing the role of the M2 muscarinic receptor pathway, we use antagonist M2 muscarinic receptors himbacine and methoctramine. Based on our previous in silico study, binding affinity of himbacine $(-8.3 \mathrm{kcal} / \mathrm{mol})$ and methoctramine $(-7.7 \mathrm{kcal} / \mathrm{mol})$ was similar to $\mathrm{M} 2$ muscarinic receptors with QNB (-11 kcal $/ \mathrm{mol})$ as a control. 4-DAMP is used as an M3 muscarinic receptor antagonist, because it has a binding affinity for the M3 muscarinic receptor $(-10.4 \mathrm{kcal} / \mathrm{mol})$ compared to the tiotropium control $(-9.6$ $\mathrm{kcal} / \mathrm{mol})$. Therefore, it can be concluded that himbacine and methoctramine have good interactions with $\mathrm{M} 2$

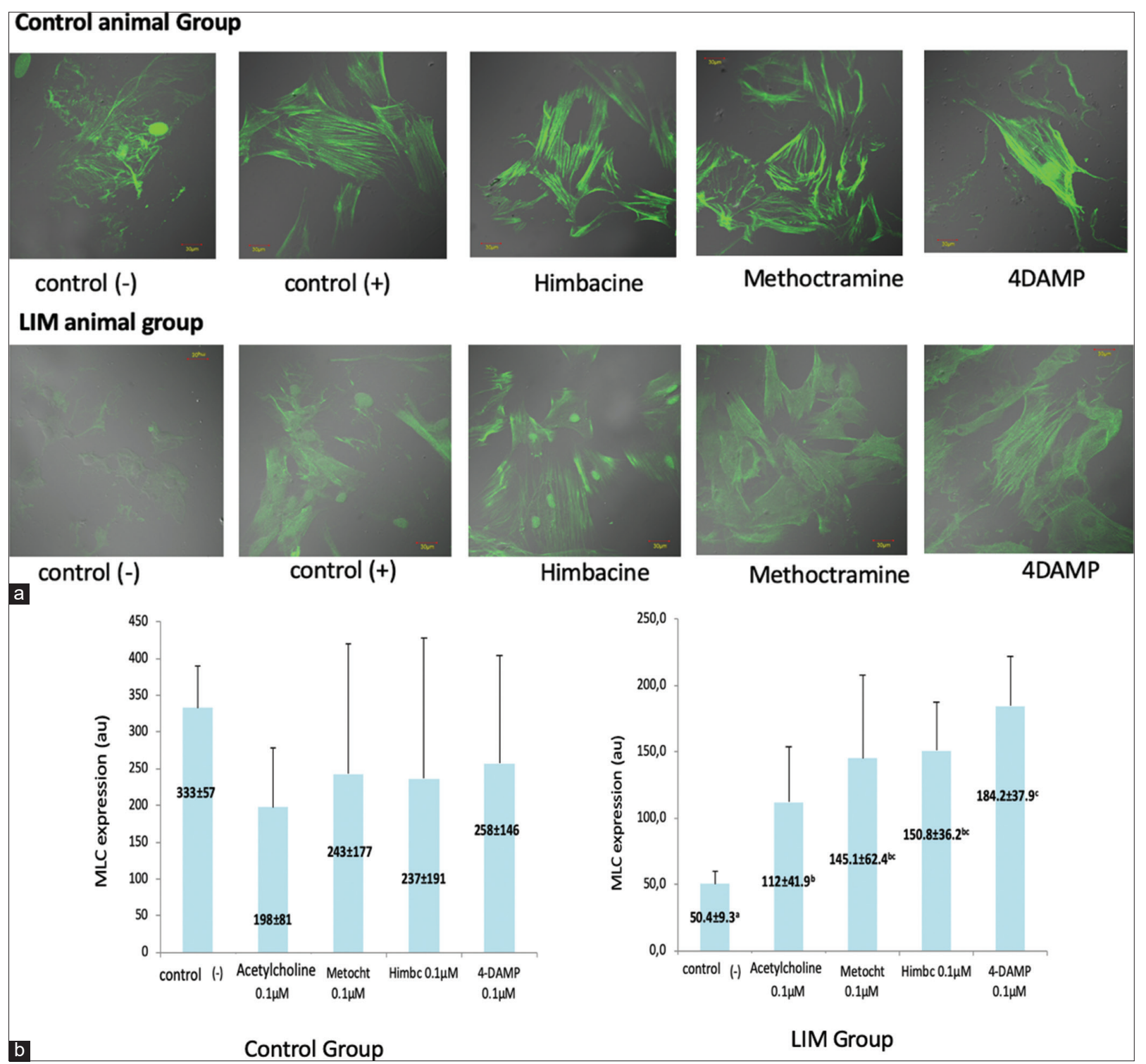

Figure 6: The phosphorylated myosin light chain expression in control and lens-induced myopia of scleral fibroblast cells Rattus norvegicus 
while 4-DAMP has good interactions with M3 muscarinic receptors. In our in vitro study, both the control and LIM groups treated with $0.1 \mu \mathrm{M}$ methoctramine resulted in lower cAMP concentration compared to the groups treated with himbacine. Whereas based on our in silico study, himbacine and methoctramine have similar binding affinity strengths with M2 muscarinic receptors [21].

Figure 2 describes the concentration of cAMP, particularly the negative control group, where in the control group, it has an opposite response than that of in the LIM group. In the control group, the cAMP concentrations increase slightly in the $5^{\text {th }}$ min and decrease in the $10^{\text {th }} \mathrm{min}$. Meanwhile, in the negative control of the LIM group, there is an increase of cAMP concentrations in the $30^{\text {th }} \mathrm{min}$. In the control group, the highest cAMP concentration is found in the himbacine group at the $5^{\text {th }} \mathrm{min}$, and though there is a decrease, there is still an activity occurring in the $10^{\text {th }} \mathrm{min}$. In the LIM group, the cAMP concentrations in 4-DAMP are higher than the himbacine group at the $10^{\text {th }} \mathrm{min}$. Based on our data, the increase of cAMP after addition of antagonist of M2 muscarinic receptor is expected, the protein $G$ of M2 muscarinic receptors in the scleral of $R$. norvegicus is dominated by GPCR, because when the culture was stimulated with the antagonist muscarinic $\mathrm{M} 2$ receptor, the reaction acted like the agonist reaction.

CAMP is the second messenger of M2 muscarinic GPCRs. Research conducted by Tao et al. (2013) found that cAMP has a role in the progression of myopia through scleral remodeling and collagen synthesis. Guinea pig group that was induced with myopia using the FDM method showed an increase in cAMP compared to the control group. Human fibroblast cell cultures that were given forskolin to stimulate $A C$ for CAMP induction cause a decrease of type 1 collagen expression, where type 1 collagen is $90 \%$ of the collagen type in sclera responsible for sclera strength [4].

In our study, we found that in a control group, the highest cAMP concentration is found in $0.1 \mu \mathrm{M}$ himbacine treatment, an antagonist M2 muscarinic receptor. It describes that the M2 muscarinic receptors are dominant in myopia development. This study supports the study of Barathi et al. (2013) that stated that the M2 muscarinic receptors have an important role in myopia progression and are dominant in scleral fibroblast cell [22]. Our data in the LIM group showed that the cAMP concentration increased in the HIMBACINE and 4-DAMP treatment. Based on this data, the increase of cAMP concentration the control and LIM groups might not be related to collagen synthesis, it is more likely to be related to cell contraction to maintain scleral strength in myopia development.

This phenomenon is supported by other studies that in smooth muscle contraction mechanism, M2 muscarinic receptor and M3 muscarinic receptor have possible interaction. The M2 muscarinic receptors affect contraction indirectly through $\mathrm{Ca}^{2+}$ entry into the cell, while the M3 muscarinic receptor regulates contraction through voltage-dependent and voltage-independent $\mathrm{Ca}^{2+}$ entry and intracellular $\mathrm{Ca}^{2+}$ release. Stimulating both $\mathrm{M} 2$ and
M3 muscarinic receptors continuously can reduce the M2 muscarinic receptors activity in contraction because M3 muscarinic receptors also cause the inactivation of $\mathrm{Ca}^{2+}$ channels [23]. This is appropriate with our data of cAMP concentration in the LIM group where cAMP concentration increased in both the 4-DAMP and himbacine groups, though the cAMP concentration in the 4-DAMP group is slightly higher than the himbacine group.

Figure 3 describes the IP3 concentration in the control and LIM groups. IP3 is a second messenger in the cell, regulating the intracellular $\mathrm{Ca} 2+$ concentration. The IP3 is formed from two pathways, namely, the coupled GPCR, Gq that activates PLC isozyme, and tyrosine kinase through PLC. The coupled GPCRs and tyrosine kinase are located in the cell membrane. When they are activated, they will hydrolyze PIP2 through PLC to IP3 and DAG. IP3 binds into the IP3 receptor, a protein that forms a gate for $\mathrm{Ca}^{2+}$ in the ER membrane. It helps the $\mathrm{Ca}^{2+}$ release into the cytoplasm that is related to the rule of fibroblast cell contraction [7], [24], [25]. The previous studies conducted by Jobling et al. (2009) found that the induction of myopia will stimulate contractions in fibroblast cells that stimulate the extracellular matrix contraction. Based on this, we predicted the increase of IP3 concentration describes the scleral fibroblast contractions. This is a mechanism to maintain the shape and length of the eyeball when being induced for myopia.

In our study, both the control and LIM groups, the IP3 concentration in the acetylcholine group at the $0^{\text {th }}$, $5^{\text {th }}$, and $10^{\text {th }}$ min has the same response as the negative control group. After the $10^{\text {th }} \mathrm{min}$, the IP3 concentrations in the negative control and acetylcholine groups increased in the control group (Figure 4), contrary to the LIM group's response (Figure 5). The IP3 concentrations in the himbacine group have the same line pattern in the control group and the LIM group. Interestingly, the IP3 concentration in the methoctramine group decreased after $20 \mathrm{~min}$ in both the control and the LIM groups. Meanwhile in the 4-DAMP group, after $5 \mathrm{~min}$, the IP3 concentrations increased in the control group and decreased in the LIM group. Based on these results in the LIM group, it appears that both M2 muscarinic receptor antagonists, himbacine and methoctramine, have different effect to IP3 concentration. Thus, more explanations about these phenomena are needed.

$\mathrm{Ca}^{2+}$ activities in the control group were found to be higher in the negative control group compared to all of the treatment groups (Figure 4). In comparison to the LIM group, the $\mathrm{Ca}^{2+}$ concentration which stands out belongs to the 4-DAMP treatment. This phenomenon cannot be confirmed for certain, the increased $\mathrm{Ca}^{2+}$ concentration in the LIM group is due to LIM treatment compensation, which is a stressor of scleral tissue, and the highest was found in the 4-DAMP treatment group, which is a M3 muscarinic selective antagonist that acts as an inhibitor of IP3 activities related to intracellular $\mathrm{CA}^{2+}$ concentration. Considering the fact that intracellular $\mathrm{Ca}^{2+}$ concentration is determined 
by various things and in this study, knockout was not performed on other muscarinic receptors that are in the same $\mathrm{Gq}$ receptor group with $\mathrm{M} 3$, that is, $\mathrm{M} 1$ and $\mathrm{M} 5$, the possibility of $\mathrm{Ca}^{2+}$ concentration increasing in the 4-DAMP treatment group is likely because of M1 and M5 activities due to inhibition of M3, or the role of M2 in stimulating extracellular $\mathrm{Ca}^{2+}$ into the intracellular.

Based on analysis of phosphorylated MLC expression with immunofluorescent that was observed using the confocal microscope in Figure 5 and analysis illustrated with histogram graph in Figure 5, the normal rat's group shows that the highest phosphorylated MLC expression belongs to the negative control group, while the phosphorylated MLC expression on the acetylcholine, himbacine, methoctramine, and 4-DAMP treatment group is lower than the negative control group and statistics shows that these treatment groups do not affect phosphorylated MLC.

The LIM mice group contrasts with the normal mice group. Phosphorylated MLC expression on the negative control group is lower than that of other treatment groups. On the provision of acetylcholine, non-selective muscarinic receptor antagonist as a positive control shows higher phosphorylated MLC expression in comparison to the negative control group. This condition points out that the provision of nonselective muscarinic antagonist on rats can increase phosphorylated MLC, which possibly elevates the contraction of myofibroblast cells.

In this study, we discovered that the provision of 4-DAMP for the LIM group as the M3 muscarinic receptor antagonist can increase phosphorylated MLC expression. The previous theory mentioned that the M3 muscarinic path stimulates IP3, which regulates the release of $\mathrm{Ca}^{2+}$ in the cytoplasm, thus increasing phosphorylated MLC and inducing contraction [12], [26], [27]. Our study came across a different finding, the provision of $\mathrm{M} 3$ receptor antagonist can increase phosphorylated MLC expression.

There are several possible causes for the increase in phosphorylated MLC in the LIM group as a result of the M3 muscarinic antagonist. First, LIM treatment is a stressor itself for scleral tissues, including in cellular concentration, which results in a number of compensation mechanisms as efforts to maintain scleral biomechanics. Second, this study does not conduct other muscarinic receptor knockdowns, where it may be likely that the treatments that were performed show contrasting results due to compensation from other muscarinic receptors.

Crosstalk on the M2 and M3 muscarinic receptor path can occur as the compensation mechanism. There are several M2 muscarinic receptor paths that play a role in cell contraction. M2 muscarinic receptor is involved in the inhibition of relaxation through PKA, whereas the beta-gamma subunit of the M2 muscarinic receptor interacts with $\mathrm{Gq}$ which stimulates PLC beta, stimulates IP3, and increases the release of intracellular $\mathrm{Ca}^{2+} . \mathrm{M} 2$ muscarinic receptor is linked to the concentration of intracellular $\mathrm{Ca}^{2+}$ on extracellular $\mathrm{Ca}^{2+}$ influx through the cell membrane [23], [28], [29].

Hence, the changes in activities related to cAMP, IP3, $\mathrm{Ca}^{2+}$, and phosphorylated MLC expression by the M2 and M3 muscarinic receptors of the scleral fibroblast cells of myopia animal model are predicted to occur due to the interactions of the M2 and M3 muscarinic receptors as compensation reaction from other muscarinic receptors or crosstalk due to myopia induction which is a stressor on the scleral tissue. Further research is needed concerning the scleral myofibroblast differentiation and the exact mechanism of specific muscarinic receptor type pathways in pathogenesis of myopia.

\section{Conclusion}

The conclusion of this study is there are differences in the response of M2 muscarinic receptors and M3 muscarinic receptors of Rattus norvegicus LIM with Rattus norvegicus non LIM. An antagonist muscarinic receptor M2 increase cAMP and IP3 concentration, decrease $\mathrm{Ca} 2+$ concentration and phosphorylated expression in scleral fibroblast cell rat model myopia. While, an antagonist M3 muscarinic receptor increase cAMP concentration, decrease IP3 concentration, increase $\mathrm{Ca} 2+$ concentration and phosphorylated MLC ekspression in scelral fibroblast rat model myopia. These may be due to the compensatory process of M2 muscarinic receptors or M3 muscarinic receptors if one of these muscarinic receptors is inhibited thereby increasing the efficiency of the other receptors. The second possibility is that there is crosstalk between M2 muscarinic receptors and M3 muscarinic receptors on Rattus norvegicus scleral fibroblast cells as an effort to maintain scleral biomechanics against myopia induction.

\section{References}

1. Metlapally R, Wildsoet CF. Scleral mechanisms underlying ocular growth and myopia. In: Progress in Molecular Biology and Translational Science; 2015. https://doi.org/10.1016/ bs.pmbts.2015.05.005

2. Shinohara K, Yoshida $T$, Liu $H$, Ichinose $S$, Ishida $T$, Nakahama KI, et al. Establishment of novel therapy to reduce progression of myopia in rats with experimental myopia by fibroblast transplantation on sclera. J Tissue Eng Regen Med. 2018;12(1):e451-61. https://doi.org/10.1002/term.2275 PMid:28401697

3. Jiang $X$, Kurihara $T$, Kunimi $H$, Miyauchi $M$, Ikeda SI, Mori $\mathrm{K}$, et al. A highly efficient murine model of experimental myopia. Sci Rep. 2018;8(1):2026. https://doi.org/10.1038/ s41598-018-20272-w

PMid:29391484 
4. Tao Y, Pan M, Liu S, Fang F, Lu R, Lu C, et al. cAMP level modulates scleral collagen remodeling, a critical step in the development of myopia. PLoS One. 2013;8(8):e71441. https:// doi.org/10.1371/journal.pone.0071441

\section{PMid:23951163}

5. Srinivasalu N, Lu C, Pan M, Reinach PS, Wen Y, Hu Y et al. Role of cyclic adenosine monophosphate in myopic scleral remodeling in Guinea pigs: A microarray analysis. Invest Ophthalmol Vis Sci. 2018;59(10):4318-25. https://doi. org/10.1167/iovs.17-224685

PMid:30167661

6. Halls ML, Cooper DM. Regulation by Ca2+-signaling pathways of adenylyl cyclases. Cold Spring Harb Perspect Biol. 2011;3(1):a004143. https://doi.org/10.1101/cshperspect. a004143

\section{PMid:21123395}

7. Ockenga $W$, Kühne $S$, Bocksberger $S$, Banning $A$, Tikkanen R Non-neuronal functions of the M2 muscarinic acetylcholine receptor. Genes. 2013;4(2):171-97. https://doi.org/10.3390/ genes 4020171

PMid:24705159

8. Tanzarella P, Ferretta A, Barile S, Ancona M, De Rasmo D, Signorile A, et al. Increased levels of cAMP by the calciumdependent activation of soluble adenylyl cyclase in parkinmutant fibroblasts. Cells. 2019;8(3):250. https://doi.org/10.3390/ cells8030250

PMid:30875974

9. Berridge MJ. The inositol trisphosphate/calcium signaling pathway in health and disease. Physiol Rev. 2016;96(4):126196. https://doi.org/10.1152/physrev.00006.2016 PMid:27512009

10. Taylor CW. Regulation of IP3 receptors by cyclic AMP Cell Calcium. 2017;63:48-52. https://doi.org/10.1016/j. ceca.2016.10.005

PMid:27836216

11. Prole DL, Taylor CW. Inositol 1, 4, 5-trisphosphate receptors and their protein partners as signalling hubs. J Physiol. 2016;594(11):2849-66. https://doi.org/10.1113/jp271139 PMid:26830355

12. Khapchaev AY, Shirinsky VP. Myosin light chain kinase MYLK1: Anatomy, interactions, functions, and regulation. Biochemistry (Mosc). 2016;81(13):1676-97. https://doi.org/10.1134/ s000629791613006x

PMid:28260490

13. Kolodney MS, Elson EL. Correlation of myosin light chain phosphorylation with isometric contraction of fibroblasts. J Biol Chem. 1993;268(32):23850-5. https://doi.org/10.1016/ s0021-9258(20)80463-3

PMid:8226923

14. McBrien NA, Jobling Al, Gentle A. Biomechanics of the sclera in myopia: Extracellular and cellular factors. Optom Vis Sci. 2009;86(1):E23-30. https://doi.org/10.1097/ opx.0b013e3181940669

PMid:19104466

15. Jobling Al, Gentle A, Metlapally R, McGowan BJ, McBrien NA. Regulation of scleral cell contraction by transforming growth factor- $\beta$ and stress: Competing roles in myopic eye growth. J Biol Chem. 2009;284(4):2072-9. https://doi.org/10.1074/jbc. m807521200

PMid:19011237

16. Andreollo NA, dos Santos EF, Araújo MR, Lopes LR. Rat's age versus human's age: What is the relationship? Arq Bras Cir Dig. 2012;25(1):49-51.

PMid:22569979
17. Zhou X, Pardue MT, luvone PM, Qu J. Dopamine signaling and myopia development: What are the key challenges. Prog Retin Eye Res. 2017;61:60-71. https://doi.org/10.1016/j. preteyeres.2017.06.003 PMid:28602573

18. Xiao H, Fan ZY, Tian XD, Xu YC. Comparison of formdeprived myopia and lens-induced myopia in guinea pigs. Int $\mathrm{J}$ Ophthalmol. 2014;7(2):245-50. PMid:24790865

19. Mao J, Liu S, Fu C. Citicoline retards myopia progression following form deprivation in guinea pigs. Exp Biol Med (Maywood). 2016;241(11):1258-63. https://doi. org/10.1177/1535370216638773

PMid:26979720

20. Wang S, Liu S, Mao J, Wen D. Effect of retinoic acid on the tight junctions of the retinal pigment epithelium-choroid complex of guinea pigs with lens-induced myopia in vivo. Int $\mathrm{J}$ Mol Med. 2014;33(4):825-32. https://doi.org/10.3892/ijmm.2014.1651 PMid:24535401

21. Anandita NW, Sujuti $H$, Wahyuni ES, Nurdiana N. Binding affinity of selective inhibitors for M2 and M3 muscarinic acetylcholine receptors-in silico study for controlling myopia progressivity. Drug Invent Today. 2019;12(11):2624-8.

22. Barathi VA, Kwan JL, Tan QS, Weon SR, Seet LF, Goh LK, et al. Muscarinic cholinergic receptor (M2) plays a crucial role in the development of myopia in mice. Dis Model Mech. 2013;6(5):1146-58. https://doi.org/10.1242/dmm.010967 PMid:23649821

23. Unno $T$, Matsuyama $H$, Sakamoto $T$, Uchiyama $M$, Izumi $Y$ Okamoto $\mathrm{H}$, et al. $\mathrm{M}(2)$ and $\mathrm{M}(3)$ muscarinic receptor-mediated contractions in longitudinal smooth muscle of the ileum studied with receptor knockout mice. Br J Pharmacol. 2005;146(1):98108. https://doi.org/10.1038/sj.bjp.0706300

PMid:15965495

24. Resende RR, Adhikari A. Cholinergic receptor pathways involved in apoptosis, cell proliferation and neuronal differentiation. Cell Commun Signal. 2009;7:20. https://doi. org/10.1186/1478-811x-7-20 PMid: 19712465

25. Prole DL, Taylor CW. Structure and function of ip3 receptors Cold Spring Harb Perspect Biol. 2019;11(4):a035063. https:// doi.org/10.1101/cshperspect.a035063

PMid:30745293

26. Lincoln TM. Myosin phosphatase regulatory pathways: Different functions or redundant functions? Circ Res. 2007;100(1):10-2. https://doi.org/10.1161/01.res.0000255894.25293.82 PMid:17204659

27. Hirano K, Derkach DN, Hirano M, Nishimura J, Kanaide H Protein kinase network in the regulation of phosphorylation and dephosphorylation of smooth muscle myosin light chain. Mol Cell Biochem. 2003;248(1-2):105-14.

PMid:12870661

28. Unno T, Matsuyama H, Izumi Y, Yamada M, Wess J, Komori S. Roles of M2 and M3 muscarinic receptors in cholinergic nerveinduced contractions in mouse ileum studied with receptor knockout mice. Br J Pharmacol. 2006;149(8):1022-30. https:// doi.org/10.1038/sj.bjp.0706955

PMid:17099717

29. Hornigold DC, Mistry R, Raymond PD, Blank JL, Challiss RA Evidence for cross-talk between M2 and M3 muscarinic acetylcholine receptors in the regulation of second messenger and extracellular signal-regulated kinase signalling pathways in Chinese hamster ovary cells. Br J Pharmacol. 2003;138(7):134050. https://doi.org/10.1038/sj.bjp.0705178

PMid:12711635 